\section{UDC 353.7:35}

https://doi.org/10.32689/2617-22242020-4(24)-15-22

\section{Артеменко Антоніна Іванівна,}

старший викладач Київського національного економічного університету ім. В. Гетьмана, м. Київ, вул. Перемоги, 54, тел.: 57599 68, e-mail: antoninaartemenko33@gmail.com, https:// orcid.org/0000-0003-2426-875x

\section{Артеменко Антонина Ивановна,}

старший преподаватель Киевского национального экономического университета им. В. Гетьмана, г. Киев, ул. Победь, 54, тел.: 57599 68, е-таil: antoninaartemenko33@gmail.com, https:// orcid.org/0000-0003-2426-875x

\section{Artemenko Antonina Ivaniona,}

senior lecturer of the Kyiv National Economic University named after $V$. Hetman, Peremohy Street, 54, Kyiv, tel.: 57599 68, e-mail: antoninaartemenko33@gmail.com, https://orcid.org/0000-0003-2426-875x

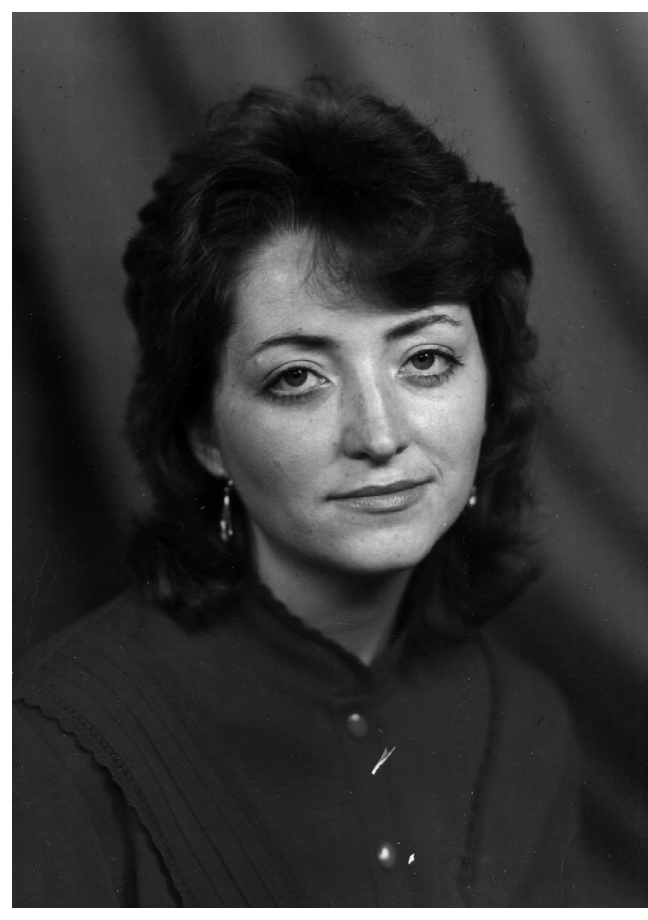

\title{
ДЕМОКРАТИЧНІ ПРИНЦИПИ ДЕРЖАВНОГО УПРАВЛІННЯ
}

Анотація. Розглянуто демократичні принципи державного управління. Об'єктивність - це найважливіша риса демократичних принципів державного управління. Демократичні принципи державного управління включають політичні, економічні та культурні принципи, які дають свободу всім людям суспільства. Демократія - одна з основних функцій державного управління, яка показує, що уряд повинен захищати права людини на свободу слова і релігії, право рівного захисту відповідно до закону і можливість організовувати і брати участь у політичному, економічному і культурному житті суспільства. Сучасні процеси демократизації призвели до скасування цієї виборчої кваліфікації. Це стосується дискримінаційних виборчих кваліфікацій, які повністю усуваються в різних країнах. Це сприяє демократизації процесів державного управління. Демократичні принципи державного управління базуються стосовно теоретичних критеріїв демократії, яка формується людською цивілізацією, які мають владу і засоби для вираження волі людей. Боротьба за демократію упродовж історії показує, що демократичні принципи державного 
управління є важливими в теперішній час. Вони можливі, якщо базуються на принципі плюралізму у взаємодії з іншими принципами і вимагають універсальної важливості для сучасної демократії. Демократичні принципи державного управління полягають у взаємодії із соціальними процесами розвитку демократичного суспільства. Вони - пряма реалізація людей як головного предмета демократичних відносин. Участь людей у державному управлінні будується на свободі зібрань та асоціацій, які докладають зусиль для того, щоб краще зрозуміти те, як краще досягти результатів ідентифікації та керування ризиками та вимірювати вплив підзвітності державного управління. Люди мають рівні права не тільки під час виборів, але і в іншому соціальному житті: економічному і культурному. Вони мають можливість впливати на справи через соціальні форми демократії.

Ключові слова: демократичні принципи, державне управління, демократія, свобода, суспільство.

\section{ДЕМОКРАТИЧЕСКИЕ ПРИНЦИПЫ ГОСУДАРСТВЕННОГО УПРАВЛЕНИЯ}

Аннотация. Рассматрены демократические принципы государственного управления. Объективность - это наиболее важная черта демократических принципов государственного управления. Демократические принципы государственного управления включают политические, экономические и культурные принципы, которые обеспечивают свободу всем людям общества. Демократия - это одна из основных функций государственного управления, которая показывает, что правительство должно защищать права человека на свободу слова и религиозность, право равной защиты в соответствии с законом и возможность организовывать и принимать участие в политической, экономической жизни общества.

Современные процессы демократизации привели к отмене самой электоральной квалификации. Это касается дискриминационных электоральных квалификаций, которые полностью устраняются в разных странах. Это способствует демократизации процессов государственного управления. Демократические принципы государственного управления базируются относительно теоретических критериев демократии, формируются человеческой цивилизацией, которые имеют власть и средства для выражения воли людей.

Борьба за демократию на протяжении истории показывает, что демократические принципы государственного управления являются важными в настоящее время. Они возможны, если базируются на принципе плюрализма во взаимодействии с другими принципами и требующие всеобщей важности для современной демократии. Демократические принципы государственного управления заключаются во взаимодействии с социальными процессами развития демократического общества.

Они - прямая реализация людей как главного объекта демократических отношений. Участие людей в государственном управлении строится на сво- 
боде собраний и ассоциаций, которые прилагают усилия для того, чтобы лучше понять то, как лучше достичь результатов идентификации и управления рисками и измерять влияние подотчетности государственного управления. Люди имеют равные права не только во время выборов, но и в другой социальной жизни: экономической и культурной. Они имеют возможность влиять на дела через социальные формы демократии.

Ключевые слова: демократические принципы, государственное управление, демократия, свобода, общество.

\section{DEMOCRATIC PRINCIPLES OF THE GOVERNANCE}

Abstract. The article examines the democratic principles of public administration. Objectivity is the most important feature of democratic principles of public administration. Democratic principles of public administration include political, economic and cultural principles providing freedom to all people in society. Democracy is one of the main functions of public administration, which shows that government should protect human rights to freedom of speech and religion, right to equal protection under the law and ability to organize and participate in political, economic and cultural life of society. Modern processes of democratization have led to cancellation of greater electoral qualifications. This applies to discriminatory electoral qualifications, which are completely eliminated in different countries. This contributes to the democratization of administrative processes. Democratic principles of public administration are based on the theoretical concept of democracy that is formed by human civilization. Democratic principles of public administration having the power and means to express the will of the people. The fight for democracy throughout history shows that democratic principles of public administration are important today. They are possible if they are based on the principle of pluralism together with other principles and require universal importance for modern democracy. Democratic principles of public administration consist in interaction with social processes of democratic society development. They are the direct representation of people as the main subject of democratic relations. The participation of people in public administration is based on freedom of meetings and associations, which make efforts to better understand how to achieve the results of risk identification and management and to measure the impact of public administration accountability. People have equal rights not only during elections, but also in other social life: economic and cultural. They have the ability to influence affairs through social forms of democracy.

Keywords: democratic principles, public administration, democracy, freedom, society.

Постановка проблеми. Демократичні принципи державного управління - це соціальне явище, яке передує появі перших державних утворень. Основні риси демократичних принципів державного управління притаманні ще стародавнім періодам цивілізації. Навіть у той час 
головним принципом управління був соціальний, який включав інтереси більшості громади загалом [1].

Нині важливо виділити такі демократичні принципи державного управління, як політичні та соціальні, які включають участь людей в діяльності державного управління та їх рівність у різних сферах. Об'єктивність є найважливішою ознакою демократичних принципів державного управління .

Демократичні принципи державного управління застосовуються для всіх видів виконавчої діяльності і для всіх управлінських структур, що діють у державі. Ці принципи є найважливішими принципами державного управління. Слід визнати, що демократії розуміють те, що однією з головних функцій державного управління є захист таких прав людини, як свобода слова та релігії, право на рівний захист відповідно до закону та можливість повноцінно організовуватись та брати участь у політичному, економічному та культурному житті суспільства.

Аналіз досліджень та публікацій. Такі науковці як К. О. Ковбасюк, Ю. П. Ващенко, Ю. П. Сурмін, А. Клейн, В. М. Козаков, Н. Латигіна, Я. Радиш, Б. Атвуд, Ч. Басіоні, О. Ф. Скакун, А. Ф. Колодій, В. І. Яловий та інші аналізують демократичні принципи державного управління. Ми можемо визнати, що вони враховують важливість демократичних принципів державного управління в даний час розвитку суспільства. Демократичні принципи державного управління можуть допомогти різним країнам розвивати своє суспільство демократично. Вчені, аналізуючи демократичні принципи державного управління, хочуть довести, що вони є важливими, якщо люди хочуть жити в сучасному суспільстві і мати політичну, економічну та культурну свободу.

Мета статті - проаналізувати демократичні принципи державного управління в даний час.

Виклад основного матеріалу. Демократичні принципи державного управління забезпечують вільні вибори для всіх громадян держави. Слід визнати, що демократичні принципи державного управління включають не лише права, а й відповідальність людей за участь у політичних системах, що захищають їх права та свободи. Демократичні принципи відповідають цінностям толерантності, співпраці та компромісу [2].

Демократичні принципи державного управління виявляються у взаємодії основних принципів: загального, спеціального та структурного.

Загальні принципи актуалізують ціннісний вимір демократії як форми організації суспільства, яка діє за принципом демократії як послідовності прав і свобод людини. Спеціальні принципи грунтуються на балансі ціннісних орієнтацій щодо державних службовців. Структурні принципи забезпечують єдність державної влади у трьох вимірах: правовому, політичному та організаційному [3].

Однією з функцій демократичних принципів державного управління є встановлення та підтримка різних рівнів суспільства. Щодо економічних рівнів суспільства, то існують зв'язки між процесами виробництва, працівниками, етапами матеріальних 
та інформаційних потоків, сутностями і об'єктами управління та зовнішні зв’язки, що являються дуже специфічними в державному управлінні та включають міжнародні, політичні, економічні та культурні відносини в сучасному суспільстві [1].

Демократичні принципи державного управління можуть грунтуватися на загальних теоретичних критеріях і принципах демократії, які формуються людською цивілізацією і розглядаються через призму культури народу. I це могло б бути реалізовано за допомогою об'єктивного механізму економічного розвитку [4].

Одним із головних механізмів формування демократичних принципів державного управління є форма реалізації суверенітету людей.

Дослідження демократичних принципів державного управління дає можливість краще зрозуміти суть сучасного суспільства та зробити його більш демократичним. Практика управління в Україні показує, що деякі демократичні принципи державного управління систематично порушуються, що робить актуальність нашого дослідження більш очевидною [5].

Основними принципами державного управління є політична свобода, право народу визначати та змінювати закони, що забезпечують захист прав людини. Свобода має рівність і нерівність між людьми.

Рівність людей означає наслідування ними законів. Політичні, релігійні, етнічні, соціальна рівність повинні бути гарантовані урядом. Демократичні принципи державного управління можуть бути створені більш відкрито в такій мірі, щоб відобразити бажання людей. Необхідно вдосконалити демократичні принципи державного управління, залучаючи більше людей і вдосконалення демократії може дати їм більше влади. Боротьба за демократію протягом всієї історії показує, що демократичні принципи державного управління $є$ дуже важливими в наш час.

Демократичні принципи державного управління повинні бути завжди сучасними та новаторськими. В результаті реалізації цих принципів переосмислюється роль державного управління та розподіл функцій між державою та суспільством, участь людей у виборах [6].

Місцеві вибори проводяться вільно відповідно до міжнародних стандартів та без будь-яких фальсифікацій. Люди є центром громадської активності і вони залучені до чітко визначених способів державного управління на місцевому рівні. Усі люди можуть мати голос у прийнятті рішень прямо чи через державне управління представляючи свої інтереси. Усі голоси беруть до уваги, включаючи розподіл ресурсів. Участь людей у державному управлінні будується на свободі зібрань та асоціацій, які докладають більш узгоджених зусиль для того, щоб краще зрозуміти, як досягти результатів ідентифікуючих та управлінських ризиків та вимірювання впливу підзвітності державного управління. Дослідження принципів державного управління є важливим у державному управлінні на сучасному етапі розвитку державного управління [7].

Демократичні принципи державного управління базуються на праві 
всіх людей брати участь у державному управлінні, вони вимагають існування представницьких інституцій на всіх рівнях і в парламенті. Демократичні принципи державного управління можуть бути представлені в парламенті, який має повноваження і означає вираження волі людей шляхом законодавства та наглядом за діями уряду [8].

Ми можемо припустити існування певної форми демократичних принципів державного управління, який може включати рівність виборів та рівність політичного впливу, включаючи плюралізм, що означає різноманітність соціальних явищ і розширює спектр політичних виборів і дозволяє не тільки плюралізм думок, а й політичний плюралізм з різними програмами та статутами, що діють в рамках законів.

Демократичні принципи державного управління можливі, коли вони базуються на принципі плюралізму в поєднанні з іншими принципами і набувають загального значення для сучасної демократії [9].

Сучасні процеси демократизації призвели до скасування найбільшої виборчої кваліфікації. Це стосується дискримінаційних виборчих кваліфікацій, які повністю усуваються в різних країнах. Це стосується демократизації процесів державного управління [5].

Демократичні принципи державного управління виявляються у взаємодії із соціальними процесами розвитку демократичного суспільства [3].

Основними об'єктами оцінки та вимірювання демократичних принципів державного управління має бути: система інститутів влади, ад- міністративний апарат, сучасне суспільство та економіка. Люди повинні залучатися до всіх цих підсистем відповідно до критеріїв та показників, що характеризують демократичність державного управління [10].

Демократичні принципи державного управління - це безпосереднє втілення людей як основного суб'єкта демократичних відносин і виявляється через участь в ньому державного управління, що означає участь у виборах та здатність впливати на справи через соціальні форми демократії та розвиток економіки, що важливо для розвитку найбільш розвиненого суспільства [11].

Ми можемо визнати, що для розвитку сучасних суспільств економічна незалежність створює фундамент для того, щоб люди були вільні у своїх діях. Демократичні принципи включають економічний плюралізм, який може контролювати владу управління [2].

Висновки. Таким чином, слід зауважити, що демократичні принципи державного управління досліджуються через аналіз демократичних процесів розвитку суспільства в даний час, коли люди можуть бути залучені до різних соціальних процесів під впливом демократії. Сучасний процес демократизації базується на плюралізмі, який включає економічні, політичні та культурні особливості. Демократичні принципи можуть включати рівноправність людей не лише на виборах і в дотриманні законів, а й в інших соціальних процесах розвитку сучасного суспільства. Демократичними принципами державного управління є політична свобода, право народу визначати та змінювати 
закони, що забезпечують захист прав людини.

Політична свобода дуже важлива для всіх людей, оскільки вони хочуть бути вільними у своїй свідомості, мати можливість висловити свою думку відповідно до демократичних процесів. Ми можемо визнати, що дослідження демократичних принципів державного управління потребує подальшого дослідження.

\section{СПИСОК ВИКОРИСТАНИХ ДЖЕРЕЛ}

1. Державне управління: підручник / ред. кол.: Ю. В. Ковбасюк, К. О. Ващенко, Ю. П. Сурмін та ін. Київ: НАДУ, 2012. Т. 1. С. 124-234.

2. Klein A. (2011).Concepts and principles of democratic governance and accountability. Uganda: Konrad-Adenauer-Stiftung. 1-11

3. Козаков В. М. Основні принципи державного управління в Україні: соціально-ціннісний аспект // Держ. упр.: удосконалення та розвиток. Д.: ТОВ “ДКС-центр”, 2010. № 12.

4. Латигіна Н. Основні критерії, принципи та рівні здійснення демократії // Політ. менеджмент. 2009. C. 81-91.

5. Бучин М. Демократичні принципи виборів: суть та типологія // Укр. нац. ідея: реалії та перспективи розвитку. Львів: Львів. політехніка, 2008. C. $32-42$.

6. Радии Я. Державне управління в Україні: стан проблеми та тенденції розвитку // Буковин. вісн. держ. служби та місцевого самоврядування. 2009. № 12. С. 11-12.

7. Atwood B. (2013). Accountability and democratic governance: orientation $\mathrm{s}$ and principles for development / OECD. $3-39$
8. Ch. Bassioni, David Beetham and al. Democrac : its principles and achievement.Geneva: Inter-Parliamentary Union. 1998. 56-65.

9. Скакун О. Ф. Теорія держави і права: підручник. Харків: Консум, 2001. С. $545-656$.

10. Колодій А. Ф. Визначення критеріїв та вимірювання демократичності врядування в Україні // Реформування системи держ. упр. та держ. служби: теорія і практика: матер. наук.-практ. конф. Львів: ЛРІДУ НАДУ, 2010. С. 29-55.

11. Яловий В. Принципи державного управління та місцевого самоврядування в умовах столичної агломерації // Вісн. Нац. акад. держ. упр. 2009. C. 181-191.

\section{REFERENCES}

1. Kovbasiuk, Yu.V. (Eds.). (2012). Derzhavne upravlinnia [Governance]. Kyiv [in Ukrainian].

2. Klein, A. (2011). Concepts and principles of democratic governance and accountability. Kampala: Konrad-Adenauer-Stiftung [in English].

3. Kozakov, V. M. (2010). Osnovni pryntsypy derzhavnoho upravlinnia v Ukraini: sotsialno-tsinnisnyi aspect [The main principles of public administration in Ukraine: social-valuable aspect]. Derzhavne upravlinnia: udoskonalennia ta rozvytok - Governance: improvement and development, 12. Retrieved from http://www. dy.nayka.com.ua/?op=1\&z=229 [in Ukrainian].

4. Latyhina, N. (2009). Osnovni kryterii, pryntsypy ta rivni zdiysnennia demokratii [Main criteria, principles and levels of implementation of democracy]. Politychnyi menedzhment - Political management, 3(36), 81-91 [in Ukrainian]. 
5. Buchyn, M. (2008). Demokratychni pryntsypy vyboriv: sut i typolohiia [Democratic principles of elections: essence and typology]. Ukrainska natsionalna ideia: realii ta perspektyvy rozvytku - Ukrainian national idea: reality and perspectives of the development, 20, 32-42 [in Ukrainian].

6. Radysh, Ya. (2009). Derzhavne upravlinnia v Ukraini :stan problemy ta tendentsii rozvytku[Governance in Ukraine:state of the problem and the tendency of the development]. Bukovynskyi visnyk derzhavnoi sluzhby ta mistsevoho samovriaduvannia Bukovynian Bulletin of Civil Service and Local Self-Government, 12, 11-12 [in Ukrainian].

7. Atwood, B. (2013). Accountability and democratic governance: orientations and principles for development. OECD [in English].

8. Bassioni, Ch. (1998). Democracy: its principles and achievement. Geneva: Inter-Parliamentary Union [in English]
9. Skakun, O. F. (2001). Teoriia derzhavy i prava [Theory of the state and the law]. Kharkiv [in Ukrainian].

10. Kolodiy, A. F. Vyznachennia kryteriiv ta vymiriuvannia demokratychnosti vriaduvannia v Ukraini [Definition of criteria and measurement of democratic governance in Ukraine]. Reformuvannya systemy derzhavnoho upravlinnia ta derzhavnoi sluzhby: teoriia i praktyka - Reforming the system of public administration and public service: theory and practice: Proceedings of scientific practical Conference. (pp. 29-35). Lviv [in Ukrainian].

11. Yalozyy, V. (2009). Pryntsypy derzhavnoho upravlinnia ta mistsevoho samovryaduvannia $\mathrm{v}$ umovah stolychnoi ahlomeratsii [Principles of the governance and the local municipality in the conditions of the capital agglomeration]. Visnyk Natsionalnoi akademii derzhavnoho upravlinnia Bulletin of the National Academy of Public Administration, 2, 181-191 [in Ukrainian]. 